“KOSAเn“ JIK. Vol. 7 No. 1 Mei 2019

\title{
ANALISIS FAKTOR-FAKTOR YANG MEMPENGARUHI KEBERHASILAN INISIASI MENYUSU DINI
}

\author{
Warsini $^{1}$, Yunistya Kusuma Wardani ${ }^{2}$
}

\begin{abstract}
Background: IMD means the start of breastfeeding in the first hour after the baby is born. The implementation of IMD helps reduce poverty, reduce hunger and reduce child mortality. Although the benefits are very large, the coverage is still not optimal, which is less than the target of Healthy Indonesia 2010 at $80 \%$.

Objective: To find out what factors can influence the success of IMD in Kedunglumbu Village, Surakarta City.

Subjects and Methods: Type of observational analytic study with crossectional design. The population of this study is mothers who have children aged 0-6 months in the Kedunglumbu area of Surakarta City in December 2018 to January 2019 with 32 being taken using saturated sampling techniques.

Research Results: Most mothers were 29 years old, 5 mothers (15.6\%), most of the mother's education levels were graduating from high school, as many as 27 mothers (44\%), most of the mother's answer scores showed a good level of knowledge as many as 31 mothers ( $96.9 \%$ ), most of the mothers did not work (IRT) as many as 16 mothers $(50 \%)$, most of the mothers did not succeed in implementing IMD as many as 17 mothers $(53.1 \%)$. The results of the analysis by Chi Square test showed that there was no relationship between the support of health workers and the success of IMD $(p=0.190)$, there was no relationship between family support and the success of IMD $(p=0.190)$, and there was no educational relationship with success in IMD $(p=0.340)$.

Conclusion: There is no relationship between health worker support and the success of IMD $(p=0.190)$, there is no relationship between family support and the success of IMD $(p=0.190)$, and there is no educational relationship with the success of IMD $(p=0.340)$.
\end{abstract}

Keywords: IMD, support, health personnel, family, education

\section{PENDAHULUAN}

IMD (Inisiasi Menyusu Dini) merupakan peristiwa yang penting dalam meningkatkan keberhasilan pemberian ASI Eksklusif. Menurut Astuti, et al. (2015 : 163), IMD memiliki arti permulaan kegiatan menyusu dalam satu jam pertama setelah bayi lahir. Pelaksanaan IMD membantu mengurangi kemiskinan, mengurangi kelaparan dan mengurangi angka kematian anak balita (Roesli, 2008 : 32). Bayi yang diberi kesempatan IMD mendapatkan manfaat dari ASI kolostrum (The gift of life) lebih dulu dari pada yang tidak diberi kesempatan. Kolostrum merupakan ASI istimewa bagi daya tahan tubuh dan penting bagi kelangsungan hidup bayi (Roesli, 2008 : 14).

IMD mempunyai manfaat untuk ibu dan bayi yaitu mendekatkan ikatan kasih sayang (bonding), bagi ibu IMD dapat membuat rahim ke ukuran semula, meredakan ketegangan dan stres, IMD dapat menyelamatkan nyawa bayi (Adiningrum, 2014 : 23).

Meskipun manfaat pelaksanaan IMD sangat besar, tetapi cakupan bayi yang diberi kesempatan IMD belum optimal. Pelaksanaan IMD di Provinsi Jawa Tengah pada tahun 2010 adalah 34\%, padahal target Indonesia Sehat 2010 sebesar $80 \%$. Sedangkan di Kota Surakarta menunjukkan 30,6\% pada tahun 
2009, dan tahun 2013 mengalami peningkatan $55,78 \%$ akan tetapi masih jauh dari standar $80 \%$ (Indramukti, 2013 : 3). Demikian juga di Kedunglumbu yang ada di Kota Surakarta, pada survei awal yang dilakukan peneliti didampingi bidan kampung Kedunglumbu ditemukan 32 ibu yang mempunyai anak usia $0-6$ bulan. Peneliti melakukan wawancara pada $10 \mathrm{ibu}$, ternyata hanya 3 ibu yang melaksanakan IMD. Hal ini mengindikasikan bahwa cakupan IMD di Kampung Kedunglumbu Kota Surakarta belum optimal.

Menurut penelitian Widiastuti, Rejeki dan Khamidah (2013), IMD dipengaruhi oleh beberapa faktor yaitu pengaruh pengetahuan perawat dan bidan terhadap pelaksanaan IMD, pengaruh sikap perawat dan bidan terhadap pelaksanaan IMD dan pengaruh pengalaman perawat maupun bidan terhadap pelaksanaan IMD. Sedangkan penelitian yang dilakukan oleh Noer, Fatimah dan Aruben (2011) faktor yang mempengaruhi pelaksanaan Inisiasi Menyusu Dini adalah pengetahuan dan motivasi ibu untuk melakukan praktik IMD, pengetahuan para ibu yang kurang mengenai IMD, kurangnya informasi yang cukup dari penyedia fasilitas kesehatan saat pemeriksaan kehamilan dan informasi dari media massa. Menurut Rosita (2008 : 109), faktor yang mempengaruhi pelaksanaan IMD adalah dukungan tenaga kesehatan, dukungan anggota keluarga, pendidikan dan pengetahuan ibu.

Pencapaian pemberian IMD di Kampung Kedunglumbu Kota Surakarta yang belum optimal ini dipengaruhi oleh beberapa faktor, akan tetapi belum pernah diteliti sebelumnya. Melihat fenomena di atas, maka peneliti memandang perlu untuk dilakukan penelitian tentang faktor - faktor yang mempengaruhi keberhasilan IMD di Kampung Kedunglumbu Kota Surakarta.

\section{TUJUAN PENELITIAN}

Untuk mengetahui faktor apa saja yang dapat mempengaruhi keberhasilan IMD di Kampung Kedunglumbu Kota Surakarta.

\section{METODE PENELITIAN}

Penelitian ini merupakan penelitian analitik dengan desain korelasi untuk mengetahui faktor-faktor yang mempengaruhi keberhasilan IMD.

\section{POPULASI, SAMPEL DAN TEKNIK SAMPLING}

Populasi penelitian ini adalah seluruh ibu yang mempunyai anak usia 0-6 bulan di wilayah Kedunglumbu Kota Surakarta pada bulan Desember 2018 sampai Januari 2019 sejumlah 32 sehingga seluruh populasi merupakan sampel yang diambil menggunakan teknik purposive.

\section{HASIL PENELITIAN}

Hasil penelitian ini dapat dijabarkan sebagai berikut:

Tabel 1.

Karakteristik Responden

\begin{tabular}{ccc}
\hline Karakteristik & $\mathrm{n}$ & $\%$ \\
\hline Umur lbu (tahun) & & \\
$20-25$ & 7 & 21,9 \\
$26-30$ & 11 & 34,4 \\
$31-35$ & 10 & 31.3 \\
$>35$ & 4 & 12,4 \\
Tingkat Pendidikan & & \\
D3 & 4 & 12,5 \\
SMA & 27 & 84,4 \\
SMP & 1 & 3,1 \\
Jenis Pekerjaan & & 3,1 \\
Swasta & 1 & 43,8 \\
Wiraswasta & 14 & 4,1 \\
PNS & 1 & 3,1 \\
IRT & 16 & 50 \\
Keberhasilan IMD & & \\
Ya & 15 & 46,9 \\
Tidak & 17 & 53,1 \\
\hline
\end{tabular}


Dari tabel 1 diketahui bahwa :

1. Umur ibu berkisar antara 20 sampai > 35 tahun (38 tahun) dengan umur ibu terbanyak adalah 29 tahun yaitu 5 ibu $(15,6 \%)$.

2. Pendidikan terakhir ibu bervariasi dari lulus SMP sampai Diploma 3 dan dikategorikan menjadi 2 yaitu tingkat pendidikan rendah jika pendidikan terakhir adalah SD sampai dengan SMP dan tingkat pendidikan tinggi jika pendidikan terakhir adalah SMA, Diploma dan Sarjana. Sebagian besar tingkat pendidikan ibu adalah lulus SMA yaitu sebanyak 27 ibu (44\%) dan paling sedikit adalah lulus SMP yaitu 1 ibu $(3,1 \%)$.

3. Pekerjaan ibu bervariasi dan dikategorikan menjadi 2 yaitu bekerja dan tidak bekerja. Dikatakan bekerja jika ibu memiliki pekerjaan di luar rumah seperti pegawai swasta, PNS dan wiraswasta dan dikatakan tidak bekerja jika mempunyai peran sebagai lbu Rumah Tangga (IRT). Sebagian besar ibu tidak bekerja (IRT) yaitu sebanyak 16 ibu $(50 \%)$ dan hanya 1 ibu yang merupakan PNS $(3,1 \%)$ dan 1 ibu $(3,1 \%)$ yang bekerja swasta sedangkan 14 (ibu 14,8\%) bekerja sebagai wiraswasta.

4. Keberhasilan IMD diketahui dari kuesioner dan buku regester persalinan. Keberhasilan IMD pada bayi dikategorikan menjadi 2 yaitu berhasil dan tidak berhasil. Sebagian besar ibu tidak berhasil melakukan IMD yaitu sebanyak 17 ibu (53,1\%) dan 15 ibu yang berhasil melakukan IMD (46,9\%).
Tabel 2.

Tabulasi Silang Variabel

\begin{tabular}{|c|c|c|c|}
\hline \multirow{2}{*}{ Variabel } & \multicolumn{2}{|c|}{ Keberhasilan IMD } & \multirow{2}{*}{$p$} \\
\hline & Berhasil & Tidak & \\
\hline \multicolumn{4}{|l|}{ Dukungan } \\
\hline \multicolumn{4}{|l|}{ Tenakes } \\
\hline Ya & 14 & 13 & 0,19 \\
\hline Tidak & 1 & 4 & 0 \\
\hline \multicolumn{4}{|l|}{$\begin{array}{l}\text { Dukungan } \\
\text { keluarga }\end{array}$} \\
\hline $\mathrm{Ya}$ & 14 & 13 & 0,19 \\
\hline Tidak & 1 & 4 & 0 \\
\hline \multicolumn{4}{|l|}{ Pendidikan } \\
\hline Rendah & 0 & 1 & 0,34 \\
\hline Tinggi & 15 & 16 & 0 \\
\hline
\end{tabular}

Dari tabel 2 diketahui tidak terdapat hubungan dukungan tenaga kesehatan dengan keberhasilan IMD $(p=0,190)$, tidak terdapat hubungan dukungan keluarga dengan keberhasilan IMD $(p=$ 0,190 ) dan tidak terdapat hubungan pendidikan dengan keberhasilan IMD $(p=0,340)$.

\section{PEMBAHASAN}

Berdasarkan karakteristik responden penelitian diketahui bahwa usia ibu mayoritas adalah 29 tahun yaitu sebanyak 5 ibu (5,6\%), dimana menurut BKKBN (2014) usia yang paling aman untuk melangsungkan kehamilan adalah 20 - 35 tahun sehingga seiring dengan himbauan dari BKKBN tersebut maka sebagian besar ibu yang mempunyai bayi termasuk dalam rentang kategori usia tersebut. Dan himbauan ini diperkuat dengan hasil penelitian menurut Yensi sebagaimana dikutip oleh Wahyuni dan Riyanti (2018) di ruang cempaka RSUD dr. Doris Sylvanus Palangka Raya bahwa dari 226 ibu bersalin di atas usia 35 tahun, sebanyak 125 orang (55,3\%) memiliki riwayat kehamilan yang tidak normal. Hal ini menguatkan teori menurut Manuaba (2007) bahwa jika seorang ibu mempunyai 
kehamilan berusia kurang dari 20 tahun dan lebih dari 35 tahun mempunyai resiko yang kurang menguntungkan baik bagi bayi dan pada usia 20 - 35 tahun seorang ibu telah benar-benar siap untuk mempunyai anak baik secara anatomi maupun secara fisiologi.

Dilihat dari karakteristik pendidikan ibu menunjukkan bahwa sebagian besar pendidikan ibu adalah SMA yaitu sebanyak 27 ibu (44\%), dimana hal ini menunjukkan bahwa himbauan Pemerintah berupaya untuk meningkatkan taraf hidup melalui sektor pendidikan bagi setiap warga negaranya sebagaimana tertuang dalam Undang-Undang Sisdiknas No. 20 Tahun 2003 Pasal 3 sebagaimana dikutip oleh Saidah (2016), yang menyatakan bahwa pendidikan berfungsi untuk mengembangkan kemampuan dan membentuk watak serta peradaban bangsa yang bermartabat dalam rangka mencerdaskan kehidupan bangsa, bertujuan untuk berkembangnya potensi peserta didik agar menjadi manusia yang beriman dan bertaqwa kepada Tuhan Yang Maha Esa, berakhlak mulia, sehat, berilmu, cakap, kreatif, mandiri, dan menjadi warga negara yang demokratis serta bertanggung jawab. Program Pemerintah tersebut yaitu pendidikan dasar wajib bagi setiap warga negara adalah adalah 9 tahun yang dapat diasumsikan pendidikan sampai tingkat SMP (Sekolah Menengah Pertama). Maka dalam penelitian ini hanya ditemukan 1 ibu saja dengan tingkat pendidikan lulus SMP.

Sebagian besar tingkat pengetahuan ibu menurut hasil penelitian ini adalah tinggi yaitu sebanyak 9 ibu $(28,1 \%)$ yang mendapatkan skor benar 17 sehingga mendapatkan nilai 85 dengan kategori pengetahuan tinggi. Tingkat pengetahuan yang tinggi ini dipengaruhi oleh banyak faktor, antara lain banyaknya informasi di media elektronik dan cetak yang menjelaskan tentang IMD dan gencarnya petugas kesehatan di daerah-daerah yang mempromosikan tentang IMD. Selain itu mayoritas ibu yang mempunyai tingkat pendidikan tinggi turut mendukung tingkat pengetahuan ibu karena menurut Notoatmojo (2010) menyatakan dengan semakin tinggi pendidikan seseorang maka akan semakin mudah dalam menerima informasi dan akhirnya mempengaruhi perilaku orang tersebut.

Berdasarkan pekerjaan maka sebagian besar ibu merupakan ibu yang tidak bekerja dengan status Ibu Rumah Tangga (IRT), yaitu sebanyak 16 (50\%). Hal ini dipengaruhi oleh budaya setempat bahwa wanita akan lebih baik jika berada di rumah dan mengurusi rumah tangga dan anggapan ini diperkuat dengan kenyataan bahwa dengan bekerja maka akan menghabiskan sebagian waktu di luar rumah sedangkan dengan adanya bayi atau anak maka menuntut waktu yang lebih banyak dari para ibu sehingga banyak dari ibu yang memilih untuk tidak bekerja karena menurut Haryono dan Setianingsih (2014) tidak mudah bagi seorang ibu yang harus merawat bayinya meskipun hal ini bukan merupakan suatu pekerjaan akan tetapi cukup menyita banyak waktu ibu. Meskipun demikian masih banyak pula ibu yang bekerja yaitu $16(50 \%)$ karena pada hakekatnya bekerja adalah sesuatu yang dilakukan untuk mendapat nafkah dan tidak dapat dipungkiri pula dengan adanya bayi akan meningkatkan pembiayaan dalam sebuah keluarga.

Berdasarkan tingkat keberhasilan IMD maka diketahui sebagian besar ibu tidak berhasil melaksanakan 
IMD yaitu 17 (53,1\%). Meskipun IMD merupakan program pemerintah tetapi capaian angka keberhasilannya belum sesuai dengan harapan, dimana hal ini dipengaruhi oleh banyak hal, antara lain adalah kondisi ibu seperti pada tindakan operasi sectio caesarea (SC) yang mendapatkan anastesi total ataupun pada keadaan kegawatan ibu maupun bayi. Hal ini seperti hasil penelitian Lestari, Zuraida dan Larasati (2013) di Kelurahan Fajar Bulan Kabupaten Lampung Barat bahwa banyak faktor yang dapat mempengaruhi perilaku seseorang termasuk dalam pelaksanaan IMD yang dapat mempengaruhi pemberian ASI Eksklusif sehingga menyebabkan angka keberhasilan IMD dan pemberian ASI Eksklusif di Indonesia masih belum optimal.

Hasil analisis bivariat menunjukkan tidak terdapat hubungan dukungan tenaga kesehatan dengan keberhasilan IMD $(p=0,190)$. Sebagaimana diketahui bahwa pada saat melahirkan memang petugas kesehatan yang selalu mendampingi ibu dan disaat itulah peran petugas kesehatan dalam mendukung pelaksanaan IMD. Hal ini berbeda dengan yang dikutip oleh Fretti, et al. (2012) menyebutkan bahwa petugas kesehatan tidak dapat bertindak sendiri dalam kegiatan IMD, banyak faktor yang dapat menciptakan peluang terlaksananya IMD antara lain kesediaan ibu bersalin, suami, keluarga, niat serta norma yang berlaku dimana semua hal tersebut akan mempengaruhi secara langsung pada perilaku ibu. Apalagi secara fisiologi ibu yang sedang melahirkan akan mengalami pembukaan mulut rahim melalui kontraksi otot uterus yang kontinyu dimana akibat kontraksi ini para ibu akan mengalami nyeri persalinan. Hasil penelitian oleh Maria, et al (2015) menunjukkan bahwa sebagian besar pasien yang melahirkan termasuk yang melalui SC mengalami nyeri dengan intensitas 4-7, dimana rasa nyari tersebut terkadang tidak tertahankan karena ambang nyeri seseorang yang bervariasi dan situasi yang tidak nyaman tersebut akan mempengaruhi perilaku ibu terkait dengan pelaksanaan IMD. Hal ini dapat dipahami bahwa saat ibu bersalin merasakan nyeri maka ibu hanya akan berfokus pada upaya mengurangi nyeri sehingga mengesampingkan upaya pelaksanaan IMD. Hal ini bertolak belakang dengan hasil penelitian oleh Hidayat (2012) dengan hasil bahwa sarana dan petugas kesehatan berpengaruh pada keberhasilan IMD. Hasil penelitian ini juga tidak sesuai dengan penelitian oleh Mesra, Rumdasih dan Fauziah (2013) yang juga menyebutkan bahwa dukungan petugas kesehatan mempengaruhi keberhasilan IMD, serta penelitian oleh Lestari di Klinik Bersalin Asih Waluyo Jati Yogyakarta yang menunjukkan bahwa dukungan petugas kesehatan akan mempengaruhi keberhasilan IMD. Hasil analisis bivariat juga menunjukkan bahwa tidak terdapat hubungan dukungan keluarga dengan keberhasilan IMD $(p=$ 0,190 ). Meskipun keluarga merupakan orang terdekat tetapi dukungan dari keluarga saja ternyata tidak dapat menjamin terlaksananya IMD. Banyak faktor yang dapat mempengaruhi keberhasilan IMD, seperti telah dikutip dalam Fretti, et al. (2012) yang menyebutkan bahwa selain dukungan keluarga masih terdapat banyak faktor yang mempengaruhi keberhasilan IMD, antara lain kesediaan ibu bersalin, niat serta norma yang berlaku dimana semua hal tersebut akan berpengaruh secara langsung terhadap perilaku 
ibu. Hasil penelitian ini sejalan dengan Issyaputri (2012) yang menyatakan bahwa tidak terdapat hubungan antara dukungan keluarga dengan keberhasilan IMD di RSIA Siti Fatimah Makasar.

Hasil analisis bivariat menunjukkan tidak terdapat hubungan pendidikan dengan keberhasilan IMD $(p=$ 0,340 ). Secara umum maka semakin tinggi tingkat pendidikan seseorang maka akan semakin mudah bagi seseorang untuk menerima segala informasi yang akan mempengaruhi perilaku seseorang tersebut yang dalam penelitian ini adalah pelaksanaan IMD. Seseorang yang berpendidikan tinggi akan berbeda perilakunya dengan orang yang berpendidikan rendah (Waryana, 2016). IMD (Inisiasi Menyusu Dini) merupakan program yang digalakkan pemerintah dalam rangka meningkatkan upaya pencapaian pemberian ASI Eksklusif. Secara teori ibu dengan tingkat pendidikan tinggi akan mempengaruhi ibu untuk melaksanakan IMD tetapi hasil pada penelitian ini tidak menemukan pengaruh tersebut. Pelaksanaan IMD memang tidak mudah mengingat kegiatan ini dilakukan pada saat ibu tengah melahirkan dan berada pada masa kesakitan akibat proses melahirkan.

\section{KESIMPULAN}

Hasil analisis dengan uji Chi Square menunjukkan tidak terdapat hubungan dukungan tenaga kesehatan dengan keberhasilan IMD $(p=0,190)$, tidak terdapat hubungan dukungan keluarga dengan keberhasilan IMD $(p=$ 0,190 ) dan tidak terdapat hubungan pendidikan dengan keberhasilan IMD $(p=0,340)$.

\section{SARAN}

1. Bagi masyarakat disarankan untuk selalu aktif dalam mengikuti program-program Pemerintah yaitu IMD dalam meningkatkan pemberian ASI Eksklusif.

2. Bagi tenaga tenaga kesehatan disarankan untuk selalu memberikan penyuluhan kesehatan untuk meningkatkan pengetahuan dan motivasi tentang pelaksanaan IMD pada setiap ibu yang akan melahirkan.

\section{DAFTAR PUSTAKA}

Adiningrum, Hapsari. 2014. Buku Pintar ASI Eksklusif. Salsabila Pustaka Alkautsar Group, Jakarta.

Astuti, Sri, et al. 2015. Asuhan Kebidanan Nifas dan Menyusui. Erlangga, Jakarta.

BKKBN. 2014. Reproduksi Sehat Sejahtera Remaja. Menteri Negara BKKBN, Jakarta.

Fretty, et al. 2012. Faktor yang Memengaruhi Bidan dalam Kegiatan Inisiasi Menyusu Dinidi Wilayah Kerja Puskesmas Onah HasangKecamatan PahaeJulu Kabupaten Tapanulu Utara. http://download.portalgaruda.o $\mathrm{rg} /$ article $=13133 \& \mathrm{val}=4108$. Diakses 10 Januari 2019.

Haryono, R. dan S. Setianingsih. 2014. Manfaat ASI Eksklusif untuk Buah Hati Anda. Gosyen Publishing, Yogyakarta.

Hidayat, K. A. 2012. Perbandingan Pelaksanaan Inisiasi Menyusu DiniBerdasar Tingkat Pengetahuan lbu Hamil. Skripsi. Universitas Diponegoro, Semarang.

Indramukti, Fifi. 2013. Faktor yang Berhubungan dengan Praktik Insiasi Menyusu Dini (IMD) pada Ibu Pasca Bersalin Normal di Wilayah Kerja Puskesmas Blado I. Unnes Jurnal Of Public Health. Vol. 1. Semarang. 
http://journal.unnes.ac.id.

Diakses pada tanggal 17

Oktober 2017.

Issyaputri, A. F. 2012. Faktor yang

Berhubungan dengan lbu

Melakukan Inisisasi Menyusu

Dini (IMD) di RSIA Siti

Fatimah Makasar Tahun 2011.

The Indonesian Journal of

Public Health. Volume 8

Nomor 4. FKM Universitas

Hasanudin, Makasar.

Lestari, D., R. Zuraida, dan T.A. Larasati. 2013. Hubungan

Tingkat Pengetahuan lbu tentang Air Susu Ibu dan Pekerjaan lbu dengan Pemberian ASI Eksklusif di Kelurahan Fajar Bulan. Medical Journal of Lampung University. Volume 2 No. 4. FK Universitas Lampung, Lampung.

Manuaba, I.B.G. 2007. Pengantar Kuliah Obstetri. EGC, Jakarta.

Maria, et al. 2015. Pengaruh Terapi Guided Imagery and Music (GIM) terhadap Skala Nyeri Luka Pasien Post Operasi Sectio Caesarea (SC) di RSUD Ende. http://ejournal.unsrat.ac.id. Diakses 12 Januari 2019

Mesra, E., J. Rumdasih dan Fauziah. 2013. Pengetahuan Inisiasi Menyusu Dini Berpengaruh terhadap Proses Laktasi.

http://ejurnal.poltekkesjakarta3 .ac.id. Diakses 11 Januari 2019.

Noer, E. R., S. Fatimah dan R. Aruben. 2011. "Praktik Insiasi Menyusu Dini dan Pemberian ASI Eksklusif pada Dua Puskesmas Kota Semarang". Media Medika Indonesia. Semarang.

http://ejournal.undip.ac.id.

Diakses pada tanggal 17 Oktober 2017.
Notoatmodjo, S. 2010. Promosi Kesehatan \& IImu Prilaku. Rineka Cipta, Jakarta.

Wahyuni, S. dan Riyanti. 2018. Perbedaan Luaran Maternal dan Perinatalpada Ibu Bersalin Usia Reproduksi Sehat dan Usia Berisiko. Jurnal Kesehatan. Volume 9 Nomor $1 . \quad$ http://ejurnal.poltekkestjk.ac.id/indek.php/JK. Diakses 12 Januari 2019.

Roesli, Utami. 2008. Insiasi Menyusu Dini Plus ASI Eksklusif. Pustaka Bunda, Jakarta.

Rosita, Syarifah. 2008. ASI untuk Kecerdasan Bayi. Ayyana Mangunnegaran, Yogyakarta.

Saidah, U. H. 2016. Pengantar Pendidikan Telaah Pendidikan Secara Global dan Nasional. PT. Raja Grafindo Persada, Jakarta.

Waryana. 2016. Promosi Kesehatan Penyuluhan dan Pemberdayaan Masyarakat. Nuha Medika, Yogyakarta.

Widiastuti, Y. P., S. Rejeki dan N. Khadimah. 2013. "Faktor faktor yang Mempengaruhi Pelaksanaan Insiasi Menyusu Dini di Ruang Mawar". Jurnal Keperawatan Maternitas. Vol. 1. Kendal. http://jurnal.unimus.ac.id.

Diakses pada tanggal 17 Oktober 2017.

1'Dosen Akper Panti Kosala

Surakarta

${ }^{2}$ Mahasiswa Akper Panti Kosala

Surakarta 